\title{
Benign Inclusions in Lymph Nodes
}

\author{
Inclusiones Benignas en Linfonodos
}

"Júlia Regazzini Spinardi; "Ísis Rocha Dias Gonçalves; *Thiago Souza La Falce;

** José Humberto Tavares Guerreiro Fregnani; ** Mirna Duarte Barros \& ** José Rafael Macéa

SPINARDI, J. R.; GONÇALVES, I. R. D.; LA FALCE, T. S.; FREGNANI, J. H. T. G.; BARROS, M. D. \& MÁCEA, J. R. Benign inclusions in limph nodes. Int. J. Morphol., 25(3):625-629, 2007.

SUMMARY: Benign inclusions are foci of non-neoplastic ectopic tissue in lymph nodes. They are classified into three types: epithelial, nevomelanocytic and decidual. It is important to identify them for the differential diagnosis with lymph node metastases, particularly among patients who present proliferative benign lesions. In general, epithelial inclusions are presented inside lymph nodes as epithelial cysts or as numerous structures resembling ducts. The cells of these structures may originate from the cells of paramesonephricus ducts, salivary glands, breast tissue, thyroid follicles, squamous epithelium or mesothelium. Paramesonephricus-type inclusions are almost exclusively found in pelvic lymph nodes and, in appearance, they resemble the epithelium of the uterine tube. Inclusions of breast tissue are composed predominantly of ectopic mammary glands and ducts that present diverse morphological characteristics that still have obscure etiology. Thyroid-type inclusions are frequently found in cervical and axillary lymph nodes, and it is believed that, embryologically, they arise from the mixing of tissues from which lymph nodes and the thyroid gland originate. Mesothelial inclusions occur preferentially in the mediastinal lymph nodes of patients who are affected by pleural or pericardial effusions. Aggregates of melanocytic cells are generally found in the lymph node capsule. The explanation for this occurrence is uncertain, but it is believed to be a consequence of incorrect migration of neural crest cells, or because of "benign metastases" of nevi present in the skin. Studies on benign inclusions in lymph nodes take on importance through assisting in correctly diagnosing the presence of metastases.

KEY WORDS: Ectopic tissues; Lymph node; Melanocyte; Paramesonephricus ducts; Thyroid gland; Breast.

\section{INTRODUCTION}

Benign inclusions are foci of non-neoplastic ectopic tissue in lymph nodes, in which different types of tissues can be seen (Fregnani et al., 2004). It is important to identify them for the differential diagnosis with lymph node metastases from adenocarcinoma, particularly among patients who present proliferative benign lesions (Leon $e t$ al., 2005; Fisher et al., 1994). The cytological and histological differences were established by Kheir et al. (1981) and are presented in Table I.

Ries was the first to report the occurrence of benign inclusions, in 1897. He described them as "tubular spaces resembling cysts", in the lymph nodes of women who underwent surgery because of malignant tumors of the uterus, cervix and vulva (Reich et al., 2000). Subsequently, Wertheim (1900) reported the presence of benign inclusions in lymph nodes in the pelvic region. He found them in $13 \%$ of their patients who underwent radical hysterectomy and pelvic lymphadenectomy, and reported them as a consequence of the neoplastic disease (Maassen \& Hiller, 1994). Other studies have demonstrated that benign inclusions are found in the lymph nodes of individuals without malignant disease. Moreover, they also occur at sites outside of the pelvic cavity, such as in lumbar, mediastinal, parotid, submandibular, jugular, hepatic and iliac lymph nodes (Maassen \& Hiller).

Brooks et al. (1990) classified the inclusions into three types: epithelial, nevomelanocytic and decidual. The relationships between the inclusion types and the topography of the lymph nodes that are preferentially affected was listed by Pantanowitz \& Upton (2003), and is shown in Table II.

Inside the lymph nodes, the epithelial inclusions are arranged in cysts or as numerous structures resembling

\footnotetext{
* Medical Student at the School of Medical Sciences of Santa Casa de São Paulo, Brasil.

* PhD. Department of Morphology of the School of Medical Sciences of Santa Casa de São Paulo, Brasil.

Source of assistance: Institutional Scientific Initiation Bursary Program - PIBIC (CNPq)
} 
SPINARDI, J. R.; GONÇALVES, I. R. D.; LA FALCE, T. S.; FREGNANI, J. H. T. G.; BARROS, M. D. \& MÁCEA, J. R. Benign inclusions in limph nodes. Int. J. Morphol., 25(3):625-629, 2007.

Table I. Criteria for differentiating between glandular epithelial inclusions and metastatic foci of adenocarcinoma in lymph nodes.

\begin{tabular}{lccc}
\hline Criteria & Item & Inclusions & Adenocarcinoma \\
\hline Histological criteria & Distribution & Around lymphoid follicle, or & Not close to lymphoid follicle \\
& Epithelium type & Pseudostratified & Numerous cell layers with \\
& Epithelium resembling uterine tube & Present & Absent \\
& Lymph node or vascular involvement & May occur & Present \\
Cytological criteria & Psammomatous bodies & Present & Present \\
& Cells with neoplastic appearance & Absent & Present \\
\hline
\end{tabular}

Kheir et al., 1981.

Table II. Topography of lymph nodes according to type of heterotopic inclusion.

\begin{tabular}{ll}
\hline Heterotopic inclusions & Lymph nodes commonly involved \\
\hline Breast tissue & Axillary \\
Aggregate of nevus cells & Axillary \\
Blue nevus & Axillary \\
Squamous epithelium & Cervical and peripancreatic \\
Salivary gland tissue & Cervical \\
Thyroid follicles & Cervical \\
Decidual tissue & Pelvic \\
Epithelium of paramesonephricus type & Pelvic \\
Intestinal glands & Mesenteric \\
Mesothelial cells & Mediastinal and retroperitoneal \\
\hline
\end{tabular}

Pantanowitz \& Upton, 2003.

ducts (Hong et al., 1988). The epithelial cells found in the inclusions may have a variety of origins, namely: paramesonephric duct cells, salivary gland cells, breast tissue cells, thyroid follicle cells, squamous epithelial cells and mesothelial cells (Piana et al., 2005).

Lymph node inclusions of paramesonephricus type are found almost exclusively in pelvic lymph nodes. Their appearance is similar to the epithelium of the uterine tube and, as such, they may imitate carcinoma metastases (Fig. 1) (Moore et al., 2000). However, cases of inclusions of this type in axillary lymph nodes have been described, coexisting with metastases in patients with breast adenocarcinoma (Piana et al.). The origin of this type of inclusion is controversial. The possibilities broached go from passage of epithelial cells through the tubal ostium for implantation in the peritoneum following peeling, followed by transportation by the lymphatic route to reach the pelvic lymph node, to metaplastic origin from the peritoneum, foci of endometriosis, or vestiges of paramesonephricus ducts. Nevertheless, other researchers have stated that the origin is in foci of indolent metastatic ovarian neoplasia (Fregnani et al.).
Inclusions of decidual type are included in the group of paramesonephricus processes. These foci originate from metaplasia that submesothelial cells are subjected to when stimulated by hormones (Alvarado Cabrero \& Sosa Romero, 2000).

Lymph node inclusions of breast tissue are predominantly composed of ectopic mammary glands and ducts with diverse morphological characteristics. However, in most cases, two cell layers are found: luminal epithelial cells and basal cells with myoepithelial differentiation (Maiorano et al., 2003; Resetkova et al., 2003). The etiology of these inclusions is still obscure (Resetkova et al., 2003; Rutty, 1994), but it is believed that they may result from capture of mammary epithelial cell remains during the embryogenesis of lymph nodes (Maiorano et al.), or from cell embolism following surgery (Rutty).

Inclusions of thyroid type are frequently found in cervical and axillary lymph nodes (Gritsman \& Schwartz, 1985). The criteria for establishing a diagnosis of benign inclusions of thyroid type in lymph nodes are: 1) The inclusions must be microscopic and be located in the subcapsular sinus of the lymph node or in close contact with it, and are generally solitary; 2) The follicles must be of regular size, containing abundant colloid, and the cells of cuboid type should be arranged in a single uniform line. Furthermore, they must not present atypical structures such as nuclear hyperchromasia, atypical mitotic figures, papillary structures or psammomatous bodies; 3 ) The thyroid gland must be clinically normal and non-palpable (Ibrahim et al., 1981). Although there is room for debate, it is believed that, embryologically, thyroid follicle inclusions arise from the mixing of the tissues from which lymph nodes and the thyroid gland originate (Rutty). 



Fig. 1. Benign epithelial inclusion in a pelvic lymph node located in the subcapsular sinus. A. Hematoxilin-eosin stain, 50X. B. Immunohistochemistry (AE1/AE3), 100X.

Mesothelial lymph node inclusions preferentially appear in the mediastinal lymph nodes of patients who are affected by pleural or pericardial effusions (Rutty; Paull \& Mosunjac, 2003). The presence of mesothelial cells in lymph nodes was observed for the first time by Brooks et al. (Brooks et al.). These authors believed that the presence of these cells in the mediastinal lymph nodes was a consequence of inflammatory processes in the pleura, which would cause rupture of the mesothelial cell layer and favor migration of some of these cells to the subpleural lymphatic capillaries and then to the lymph nodes. In 1998, Argani \& Rosai reported on a further six cases of hyperplasia of mesothelial cells in superior phrenic nodes nodes (Argani \& Rosai, 1998). They also added to the theory of Brooks et al. by explaining why these cells are not usually found in lymph nodes: unlike neoplastic cells, which are capable of proliferating, mesothelial inclusions undergo a degeneration process, and thus it becomes difficult to find them (Alvarado Cabrero \& Sosa Romero). The place where the mesothelial inclusions occur in the lymph nodes is the lymphatic sinus, unlike the paramesonephricus inclusions, which commonly occur in the lymph node capsule (Rutty; Paull \& Mosunjac).

Aggregates of melanocytic cells are generally found in the lymph node capsule (Fisher et al.). There is uncertainty regarding why melanocytic cells would be present in lymph nodes, but it is believed it might be the result from incorrect migration of neural crest cells (Rutty). Another theory presupposes the idea that "benign metastases" of the nevi present in the skin might occur (Fisher et al.). McCarthy et al. (1974) reported that, among 22 cases of melanocytic lymph node inclusions, 21 presented nevi in the skin.

Lymph node inclusions of epithelial and nevomelanocytic types are predominant in axillary lymph nodes (Fisher et al.; Piana et al.). Epithelial inclusions in axillary lymph nodes were first reported by Garret \& Ada in 1957, who found cysts with stratified squamous epithelium and numerous duct-like structures in these lymph nodes (Hong et al.). Today, studies are showing that the appearance of such inclusions is almost exclusively of glandular nature (Hong et al.). Some authors believe that ectopic breast tissue is more frequently found in sentinel lymph nodes than in other axillary lymph nodes, since it maintains a closer embryological relationship with the breast (Maiorano et al.).

Studies on benign inclusions in axillary lymph nodes take on crucial importance, insofar as they may assist in achieving a correct differential diagnosis with lymph node metastases. Considering that findings of epithelial cells in lymph nodes either by immunohistochemistry or by a biomolecular method do not necessarily imply a diagnosis of metastasis, detailed attention to the morphological evaluation of lymph nodes is merited. 
SPINARDI, J. R.; GONÇALVES, I. R. D.; LA FALCE, T. S.; FREGNANI, J. H. T. G.; BARROS, M. D. \& MÁCEA, J. R. Inclusiones benignas en linfonodos. Int. J. Morphol., 25(3):625-629, 2007.

RESUMEN: Las inclusiones benignas son focos de tejido ectópico no neoplásico en los linfonodos. Ellos son clasificados en tres grupos: epitelial, nevomelanocítico y decidual. Es importante identificarlos para el diagnóstico diferencial con metástasis de linfonodos, particularmente en aquellos pacientes que presentan lesiones proliferativas benignas. En general, las inclusiones epiteliales se presentan dentro de los linfonodos como quistes epiteliales o como numerosas estructuras que parecen conductos. Las células de estas estructuras se pueden originar a partir de las células del conducto paramesonéfrico, glándulas salivales, tejido mamario, folículos tiroideos, epitelio escamoso o mesotelio. Las inclusiones tipo paramesonéfrico son exclusivamente encontradas en los linfonodos pélvicos y su apariencia recuerda el epitelio de la tuba uterina. Las inclusiones del tejido mamario están compuestas predominantemente de tejido mamario glandular ectópico y los ductos presentan diversas características morfológicas las que no tienen una clara etiología. Las inclusiones del tipo tiroideas son frecuentemente encontradas en los linfonodos cervicales y axilares y se cree que embriológicamene, se originan de una mezcla de tejidos de que origina linfonodos y tejido glandular tiroideo. Las inclusiones mesoteliales ocurren preferentemente en los linfonodos mediastínicos de pacientes que son afectados por dilataciones pleurales y pericárdicas. Los agregados de células melanocíticas son generalmente encontrados en la cápsula de los linfonodos. La explicación para este hecho es incierta, pero se cree que es una consecuencia incorrecta de la migración de células de la cresta neural o por metástasis benignas de nevos presentes en la piel. Los estudios de las inclusiones benignas en linfonodos toma importancia ya que a través de ellos se puede ayudar a un correcto diagnóstico de la presencia de metástasis.

PALABRAS CLAVE: Tejidos ectópicos; Linfonodo; Melanocito; Conducto paramesonéfrico; Glándula tiroides; Mama.

\section{REFERENCES}

Alvarado Cabrero, I. \& Sosa Romero, A. Inclusiones epiteliales benignas en ganglios linfáticos pélvicos. Informe de dos casos. Ginecol. Obstet. Mex., 68:77-81, 2000 .

Argani, P. \& Rosai, J. Hyperplastic mesothelial cells in lymph nodes: report of six cases of a benign process that can stimulate metastatic involvement by mesothelioma or carcinoma. Hum. Pathol., 29(4):339-46, 1998.

Brooks, J. S.; LiVolsi, V. A. \& Pietra, G. G. Mesothelial cell inclusions in mediastinal lymph nodes mimicking metastatic carcinoma. Am. J. Clin. Pathol., 93(6):741-8, 1990.

Fisher, C. J.; Hill, S. \& Millis, R. R. Benign lymph node inclusions mimicking metastatic carcinoma. J. Clin. Pathol., 47(3):245-7, 1994.

Fregnani, J. H.; Latorre, M. R.; Soares, F. A.; Barros, M. D. \& Macéa, J. R. Estudo de inclusões epiteliais benignas nos linfonodos pélvicos de pacientes com carcinoma de colo de útero. AMHFCMSCSP., 49(2/3):61-5, 2004.

Garret, R. \& Ada, A. E. Epithelial inclusion cysts in an axillary lymph node; report of a case simulating metastatic adenocarcinoma. Cancer,10(1):173-8, 1957.

Gritsman, A. Y. \& Schwartz, A. M. Benign glandular inclusions. Arch Pathol Lab Med., 109(5):389-90, 1985.
Hong, H. Y.; Ruffolo, P. R. \& Srinivasan, K. Benign epithelial inclusion cyst in an axillary lymph node. $N$. Y. State. J. Med., 88(7):384-5, 1988.

Ibrahim, N. B.; Milewski, P. J.; Gillett, R. \& Temple, J. G. Benign thyroid inclusions within cervical lymph nodes: an alarming incidental finding. Aust. N. Z. J. Surg., 51(2):188-9, 1981.

Kheir, S. M.; Mann, W. J. \& Wilkerson, J. A. Glandular inclusions in lymph nodes. The problem of extensive involvement and relationship to salpingitis. Am. J. Surg. Pathol., 5(4):353-9, 1981.

Leon, X.; Sancho, F. J.; Garcia, J.; Sanudo, J. R.; Orus, C. \& Quer, M. Incidence and significance of clinically unsuspected thyroid tissue in lymph nodes found during neck dissection in head and neck carcinoma patients. Laryngoscope, 115(3):470-4, 2005.

Maassen, V. \& Hiller, K. Glandular inclusions in lymph nodes: pattern of distribution and metaplastic transformation. Arch. Gynecol. Obstet., 255(1):1-8, 1994.

Maiorano, E.; Mazzarol, G. M.; Pruneri, G.; Mastropasqua, M. G.; Zurrida, S.; Orvieto, E. et al. Ectopic breast tissue as a possible cause of false-positive axillary sentinel lymph node biopsies. Am. J. Surg. Pathol., 27(4):5138, 2003. 
McCarthy, S. W.; Palmer, A. A.; Bale, P. M. \& Hirst, E. Naevus cells in lymph nodes. Pathology, 6(4):351-8, 1974.

Moore, W. F.; Bentley, R.C.; Berchuck, A. \& Robboy, S. J. Some mullerian inclusion cysts in lymph nodes may sometimes be metastases from serous borderline tumors of the ovary. Am. J. Surg. Pathol., 24(5):710-8, 2000.

Pantanowitz, L. \& Upton, M. P. Benign axillary lymph node inclusions. Breast J., 9(1):56-7, 2003.

Paull, G. \& Mosunjac, M. Fine-needle aspiration biopsy and intraoperative cytologic smear findings in a case of benign mesothelial-cell inclusions involving a lymph node: case report and review of the literature. Diagn. Cytopathol., 29(3):163-6, 2003.

Piana, S.; Asioli, S. \& Cavazza, A. Benign Mullerian inclusions coexisting with breast metastatic carcinoma in an axillary lymph node. Virchows Arch., 446(4):4679, 2005.

Reich, O.; Tamussino, K.; Haas, J. \& Winter, R. Benign mullerian inclusions in pelvic and paraaortic lymph nodes. Gynecol. Oncol., 78(2):242-4, 2000.

Resetkova, E.; Hoda, S. A.; Clarke, J. L. \& Rosen, P. P. Benign heterotopic epithelial inclusions in axillary lymph nodes. Histological and immunohistochemical patterns. Arch. Pathol. Lab. Med., 127(1):e25-7, 2003.

Rutty, G. N. Benign lymph node inclusions. J. Pathol., 173(4):301-2, 1994.

Wertheim E. Zur Frage der Radikaloperation beim Uteruskrebs. Arch Gynäkol, 61:627, 1900.
Correspondence to:

Dra. Mirna Duarte Barros

Departamento de Morfologia - FCMSCSP

Rua Dr. Cesário Motta Júnior, 61, $11^{\circ}$ andar

CEP: 01221-020

São Paulo (SP

BRASIL

Fax : 11-2176-7000. Extension 5509.

Email: mirna.barros@fcmscsp.edu.br

Recibido : 22-03-2007

Aceptado: 17-06-2007 
